\title{
PERAN KUALITAS LAYANAN DAN KUALITAS SISTEM ENTERPRISE RESOURCE PLANNING (ERP) DALAM MENINGKATKAN KEPUASAN PENGGUNA DILINGKUNGAN UNIVERSITAS PADJADJARAN
}

\author{
Beti Buanawati, Haila Sopa, Nandang Harun, dan Rosaria Mita Amalia \\ Fakultas Ilmu Budaya Universitas Padjadjaran \\ E-mail: Beti.buanawati@unpad.ac.id
}

\begin{abstract}
ABSTRAK. Penelitian ini bertujuan untuk menguji secara empiris pengaruh kualitas layanan dan kualitas sistem terhadap kepuasan pengguna di lingkungan Universitas Padjadjaran.Analisis ini menggunakan variabel independen yaitu kualitas layanan dan kualitas system.Variabel dependennya adalah kepuasan pengguna.Sampel penelitian ini adalah para Pemegang Uang Muka Kerja (PUMK) di lingkungan Universitas Padjadjaran yang menggunakan sistem Enterprise Resource Planning (ERP).Sampel dilakukan dengan metode sampling jenuh.Pengumpulan data dilakukan dengan kuesioner yang disebarkan langsung ke PUMK sebanyak 20 kuesioner. Metode statistik menggunakan Analisis Regresi Linear Berganda, dengan pengujian hipotesis uji statistik t dan uji F.Hasil penelitian ini mengindikasikan bahwa secara parsial kualitas layanan berpengaruh positif terhadap kepuasan pengguna sistem Enterprise Resource Planning (ERP), sedangkan kualitas sistem tidak berpengaruh signifikan terhadap kepuasan pengguna sistem Enterprise Resource Planning (ERP). Sedangkan secara simultan mengindikasikan bahwa kualitas layanan dan kualitas sistem secara bersama-sama berpengaruh terhadap kepuasan pengguna sistem Enterprise Resource Planning (ERP) di lingkungan Universitas Padjadjaran.
\end{abstract}

Kata kunci: Enterprise Resource Planning; kualitas layanan; kualitas sistem dan kepuasan pengguna.

\section{ROLE OF QUALITY OF SERVICES AND QUALITY OF ENTERPRISE RESOURCE PLANNING (ERP) SYSTEMS IN IMPROVING SATISFACTION OF ENVIRONMENTAL USERS IN PADJADJARAN UNIVERSITY}

\begin{abstract}
This study aims to empirically examine the effect of service quality and system quality on user satisfaction in Universitas Padjadjaran. This analysis uses independent variables namely service quality and system quality. The dependent variable is user satisfaction.The sample of this study is the holders of Work Advances (PUMK) in Universitas Padjadjaran who use the Enterprise Resource Planning (ERP) system. The sample is done by using saturated sampling method. Data collection was done with a questionnaire that was distributed directly to the PUMK as many as 20 questionnaires. The statistical method uses Multiple Linear Regression Analysis, by testing the hypothesis test statistic $t$ and $F$ test. The results of this study indicate that partially service quality has a positive effect on user satisfaction in Enterprise Resource Planning (ERP) systems, while system quality has no significant effect on user satisfaction in Enterprise Resource Planning (ERP) systems. While simultaneously this result of this research indicates that service quality and system quality together influence the user satisfaction of the Enterprise Resource Planning (ERP) system in Universitas Padjadjaran.
\end{abstract}

Key words: Enterprise Resource Planning (ERP); service quality; system quality and user satisfaction.

\section{PENDAHULUAN}

Semakin canggihnya teknologi digital dewasa ini membuat perubahan besar tehadap dunia usaha. Hal itu ditandai dengan lahirnya berbagai macam teknologi digital yang semakin berkembang pesat. Seiring dengan perkembangan teknologi informasi dan peningkatan kebutuhan informasiyang dibutuhkan oleh perusahaan, maka perusahaan harus berlomba-lomba untuk mengimbangi seoptimal mungkin sistem informasi yang terus berkembang tersebut. Perkembangan ini memberikan tantangan baru bagi perusahaan untuk terus mengembangkan sistem informasi perusahaannya agar bisa bersaing dengan perusahaan yang lebih besar yaitu dengan mengaplikasikan sistem informasi yang mutakhir.

Sistem informasi yang mutakhir diharapkan bisa memberikan kemudahan dan informasi yang akurat bagi perusahaan sehingga bisa bersaing dengan perusahaanperusahaan lainyang lebih besar. Untukmemenuhituntutan tersebut perusahaan perlu mengimplementasikan suatu sistem teknologi informasi yang terintegrasi yaitu yang berkaitan dengan proses penginputan, dan pengolahan data yang terhubung satu dengan yang lainnya. Sehingga bisa mempercepat proses dengan hasil yang optimal dan bermanfaat bagi seluruh lini perusahaan. Sistem tersebut dikenal sebagai Enterprise Resources Planning (ERP).

Enterprise Resource Planning (ERP) merupakan Sistem Informasi Teknologi yang banyak digunakan oleh perusahaan-perusahaan kelas dunia untuk meningkatkan kinerjanya. Alasan terbesar perusahaan-perusahaan tersebut mengimplementasikan Enterprise Resource Planning (ERP) yaitu untuk mengintegrasikan proses bisnis yang telah ada secara keseluruhan ke dalam sebuah sistem komputer yang mampu melayani semua kebutuhan perusahaan.

Sebagai Perguruan Tinggi Negeri Universitas Padjadjaran adalah salah satu yang mulai mengimplementasikan sistem Enterprise Resource Planning (ERP) berbasis Oracle disetiap aktivitas bisnis yang dilakukan. Penerapan sistem Enterprise Resource Planning (ERP) tersebut merupakan upaya Universitas Padjadjaran dalam mengintegrasikan teknologi digital ke dalam aktivitas kelembagaan untuk meningkatkan kecepatan pengurusan, transportasi, hingga akuntabilitas. Pemilihan ERP tersebut 
dilakukan atas beberapa pertimbangan seperti ketersediaan dan kelengkapan modul, kemudahan implementasi, kemudahan penggunaan aplikasi, kemudahan set up pada system existing yang telah dimiliki Universitas Padjadjaran, success story pada institusi sejenis dan rekam jejak para pengguna. (Hendriyanah, A.http://www.unpad. ac.id/2016/07/.)

Dalam pengimplementasian Enterprise Resource Planning (ERP) berbasis Oracle di Universitas Padjadjaran masih terdapat berbagai macam kendala yaitu diantaranya adanya keterbatasan pengetahuan tentang Enterprise Resource Planning (ERP) dari pengguna, selalu ada perubahan-perubahan sistem tanpa sosialisasi terlebih dahulu pada pengguna sehingga membingungkan bagi pengguna (sistem kurang user friendly).

Untuk bisa menilai keberhasilan implementasi suatu sistem bisa dilihat dari bagaimana sistem tersebut dapat memenuhi kebutuhan bisnis perusahaan, dan memberikan manfaat bagi perusahaan. Keberhasilan implementasi sistem tersebut tidak terlepas dari bagaimana sistem tersebut dapat dioperasikan dan memberikan kemudahan kemudahan bagi penggunanya, sehingga dapat memberikan kepuasan bagi penggunanya. Kepuasan pengguna mencerminkan seberapa besar kepercayaan para pengguna kepada suatu sistem informasi yang disediakan untuk memenuhi kebutuhan informasi mereka.

Tujuan yang ingin dicapai dalam penelitian ini yaitu: 1). untuk mengetahui kualitas layanan Enterprise Resource Planning (ERP) pada pengguna di lingkungan Universitas Padjadjaran; 2). untuk mengetahui kualitas sistem Enterprise Resource Planning (ERP) pada pengguna di lingkungan Universitas Padjadjaran; 3). untuk mengetahui kepuasan pengguna sistem Enterprise Resource Planning (ERP) di lingkungan Universitas Padjadjaran; 4) untuk mengetahui kualitas layanan dan kualitas sistemEnterprise Resource Planning (ERP) secara parsial terhadap kepuasan pengguna di lingkungan Universitas Padjadjaran; 5) untuk mengetahui kualitas layanan dan kualitas system Enterprise Resource Planning (ERP) secara simultan terhadap kepuasan pengguna di lingkungan Universitas Padjadjaran.

Kualitas layanan menurut Tjiptono (2014: 268) "kualitas pelayanan berfokus pada upaya pemenuhan kebutuhan dan keinginan konsumen serta ketepatan penyampaianya untuk mengimbangi harapan konsumen". Menurut Tjiptono dan Chandra (2012:180) "kualitas pelayanan adalah sebagai alat ukur seberapa bagus tingkat pelayanan yang diberikan mampu sesuai dengan ekspektasi pelanggan”. Menurut Kotler(2009:83) “kualitas pelayanan harus diawali dari kebutuhan pelanggan dan diakhiri pada persepsi pelanggan". Sedangkan menurut Rambat (2014:70) "kualitas pelayanan menjadi suatu keharusan yang harus dilakukan perusahaan supaya mampu bertahan dan tetap mendapatkan kepercayaan pelanggan". Dari pengertian-pengertian tersebut menunjukkan bahwa kualitas pelayanan dapat diwujudkan melalui tingkat layanan yang diberikan oleh sistem informasi yang sesuai dengan ekspektasi pengguna sehingga bisa mendapatkan kepercayaan dari para pengguna sistem informasi tersebut. Hal tersebut sesuai dengan penelitian Asnawi (2014) yang menunjukkan bahwa kualitas sistem, kualitas informasi, kualitas layanan dan partisipasi pengguna berpengaruh terhadap kepuasan pengguna sistem secara parsial maupun simultan. Jika kualitas layanan yang dihasilkan sistem informasi semakin handal, berwujud, empati, daya tanggap dan jaminan yang baik, maka akan semakin meningkatan kepuasan pengguna.

Kualitas sistem informasi di definisikan oleh Davis et al dan juga Chin dan Todd dalam Rukmiyati dan Budiartha (2016) "kualitas sistem informasi di definisikan sebagai perceived ease of use yang merupakan seberapa besar teknologi komputer dirasakan relatif mudah untuk dipahami dan digunakan”. Menurut Susanto (2013: 16) "kualitas sistem informasi akuntansi sebagai konsep yang harus diintegasikan dengan semua unsur dan sub unsur yang terkait dalam membentuk suatu sistem informasi akuntansi untuk menghasilkan informasi akuntansi berkualitas. Unsur-unsur tersebut disebut juga sebagai komponen sistem informasi akuntansi yang terdiri dari hardware, software, brainware, prosedur, database dan jaringan komunikasi”. Sedangkan menurut Tananjaya (2012) "kualitas sistem informasi merupakan kualitas suatu produk atau pelayanan yang pada umumnya diukur berdasarkan kecocokan pemakai dengan sistem informasi tersebut, dimana sistem informasi mampu diaplikasikan sesuai dengan apa yang diinginkan oleh pemakai". Dari pengertian-pengertian tersebut menunjukkan bahwa kualitas sistem merupakantingkat kualitas dari sistem informasi tersebut apakah memberikan kemudahan bagi pengguna sehingga pengguna dapat mengaplikasikannya sesuai dengan yang diharapkan dan dapat menghasilkan suatu informasi yang akurat, tepat waktu, relevan dan lengkap serta dapat meningkatkan kinerja secara keseluruhan. Hal tersebut sesuai dengan penelitian Prasojo (2015)yang menyimpulkan bahwa kualitas informasi, kualitas sistem, dan kualitas layanan berpengaruh signifikan terhadap kepuasan pengguna secara simultan, serta membuktikan bahwa kualitas informasi, kualitas sistem, dan kualitas layanan berpengaruh positif dan signifikan terhadap kepuasan pengguna. Semakin besar keyakinan pengguna terhadap kualitas sistem yang digunakan, maka mereka akan semakin sering menggunakan sistem tersebut, karena hasil olahan informasinya yang memuaskan.

Kepuasan pengguna sistem informasi menunjukkan seberapa jauh pemakai puas dan percaya pada sistem informasi yang disediakan untuk memenuhi kebutuhan mereka. (Ives, Et al., dalam Komara, 2006). Kepuasan pengguna sistem informasi merupakan tingkat kepuasan pemakai terhadap software akuntansi yang digunakan dan output yang dihasilkan oleh software tersebut. (Istianingsih dan Wijanto, 2008). Sedangkan Jogiyanto (2007:23) 
mendefinisikan "kepuasan pemakai (user satisfaction) adalah respon pemakai terhadap penggunaan keluaran sistem informasi". Dari pengertian tersebut menunjukan bahwa kepuasan pengguna dapat diukur melalui respondan umpan balik dari pengguna sistem setelah memakai sistem informasi tersebut untuk memenuhi kebutuhan informasi mereka.

\section{Paradigma Penelitian dan Hipotesis}

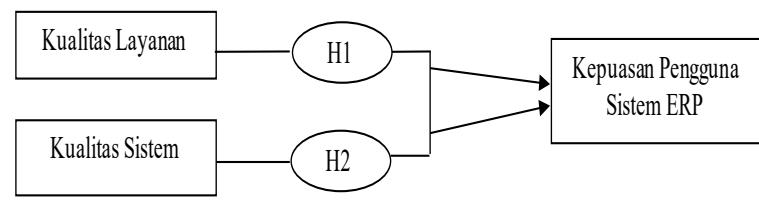

Sumber : Dokumen pribadi

\section{Gambar 1. Paradigma Penelitian}

Keberhasilan suatu sistem informasi dapat dilihat dari bagaimana sistem informasi tersebut mamapu dipahami dan dioperasikan oleh pengguna dengan efektif, dan pengguna merasa puas menggunakan sistem tersebut dan juga bagaimana perusahaan dapat memperoleh keuntungan dari sistem yang digunakannya.

DeLone dan McLean (1992) menemukan bahwa kualitas pelayanan menjadi lebih penting dibandingkan penerapan lainnya, karena pemakai sistem merupakan sebagai para pelanggan dan bukan sebagai karyawan atau pemakai internal organisasi. Oleh karenanya dengan dukungan yang jelek akan menyebabkan kehilangan pelanggan dan bahkan akan kehilangan penjualan. Menurut Tjiptono (2014) kualitas pelayanan dapat dinilai dengan menggunakan kriteria :(1) tampilan fisik (tangible); (2) keandalan (reliability); (3) daya tanggap (responsiveness); (4) jaminan (assurance); dan (5) empati (emphaty). Berdasarkan penelitian yang dilakukan olehAsnawi (2014) mengungkapkan bawa kualitas sistem, kualitas informasi, kualitas layanan dan partisipasi pengguna berpengaruh terhadap kepuasan Pengguna sistem secara parsial maupun simultan. Begitupun dengan penelitian Prasojo (2015) mengungkapkan bahwa kualitas informasi, kualitas sistem, dan kualitas layanan berpengaruh signifikan terhadap kepuasan pengguna secara simultan, serta membuktikan bahwa kualitas informasi, kualitas sistem, dan kualitas layanan berpengaruh positif dan signifikan terhadap kepuasan pengguna. Selain itu penelitian Agustina (2018) mengungkapkan secara simultan kualitas sistem, kualitas informasi, dan kualitas layanan berpengaruh signifikan terhadap kepuasan pengguna sedangkan secara parsial hanya kualitas informasi dan kualitas layanan yang berpengaruh terhadap kepuasan pengguna.

Berdasarkan penelitian-penelitian tersebut diatas dapat dikatakan bahwa jika kualitas layanan yang dihasilkan sistem informasi semakin baik, maka akan semakin meningkatkan kepuasan pengguna, sehingga hipotesis pertama dalam penelitian ini adalah semakin meningkatnya kualitas layanan, maka akan menyebabkan meningkatnya kepuasan pengguna.
DeLone dan McLean (1992) menemukan bahwa kualitas sistem (sistem quality) dapat mempengaruhi kepuasan pengguna (user satisfaction). Model kesuksesan DeLone dan McLean mengemukakan kualitas sistem mengukur kesuksesan teknikal, kualitas informasi mengukur kesuksesan semantik, dan pengunaan sistem, kepuasan pengguna, individual impact dan organizational impact mengukur kesuksesan keefektivan. DeLone dan McLean (2003) mengasumsikan bahwa kualitas sistem dan kualitas informasi, secara individual dan bersamasama, mempengaruhi kepuasan penggunanya.M enurut DeLone dan McLean (2003) untuk mengetahui suatu sistem itu berkualitas atau tidak, dapat dinilai dengan indikator :(1) kemudahan untuk digunakan (ease of use); (2) kecepatan akses (response time); (3) keandalan sistem (reliability); (4) fleksibilitas sistem (flexibility); dan (5) keamanan sistem (security). Berdasarkan penelitian yang dilakukan oleh Prasojo dkk (2015) mengungkapkan bahwa kualitas informasi, kualitas sistem, dan kualitas layanan berpengaruh signifikan terhadap kepuasan pengguna secara simultan, serta membuktikan bahwa kualitas informasi, kualitas sistem, dan kualitas layanan berpengaruh positif dan signifikan terhadap kepuasan pengguna. Begitupun dengan peneliti Asnawi (2014) mengungkapkan bawa kualitas sistem, kualitas informasi, kualitas layanan dan partisipasi pengguna berpengaruh terhadap kepuasan pengguna sistem secara parsial maupun simultan. Selain itu penelitiAmalia(2016)mengungkapkan bahwa kualitas sistem informasi berpengaruh signifikan terhadap kepuasan pengguna sistem informasi akuntansi, kualitas informasi tidak berpengaruh signifikan terhadap kepuasan pengguna sistem informasi akuntansi, perceived usefulness tidak berpengaruh signifikan terhadap kepuasan pengguna sistem informasi akuntansi dan kualitas sistem informasi, kualitas informasi, dan perceived usefulness secara bersama sama berpengaruh signifikan terhadap kepuasan pengguna sistem informasi akuntansi.

Berdasarkan penelitian-penelitian tersebut diatas dapat dikatakan bahwa jika pengguna sistem percaya bahwa jika kualitas sistem yangdigunakan adalah baik, maka mereka akan merasa puas menggunakan system tersebut. Sehingga hipotesis kedua dalam penelitian ini adalah semakin baik kualitas sistem maka semakin tinggi pula tingkat kepuasan pengguna karena hasil olahan informasinya yang memuaskan.

Berdasarkan pemaparan tersebut hipotesis penelitian yang diajukan adalah sebagai berikut:

Hipotesis 1: Terdapat pengaruh kualitas layanan terhadap kepuasan pengguna pada pengguna system Enterprise Resource Planning (ERP) di lingkungan Universitas Padjadjaran

Hipotesis 2: Terdapat pengaruh kualitas sistem terhadap kepuasan pengguna pada pengguna system Enterprise Resource Planning (ERP) di lingkungan Universitas Padjadjaran.

Hipotesis 3:Terdapat pengaruh antara kualitas layanan dan kualitas sistem terhadap kepuasan pengguna 
pada pengguna system Enterprise Resource Planning (ERP) di lingkungan Universitas Padjadjaran secara simultan.

\section{METODE}

Teknik analisis data dalam penelitian ini adalah analisis regresi berganda untuk melakukan pengujian mengenai pengaruh kualitas layanan dan kualitas sistem pada kepuasan pengguna system Enterprise Resource Planning (ERP) di lingkungan Universitas Padjadjaran. Sebelum analisis regresi linear berganda dilakukan uji asumsi klasik yangterdiri dari uji normalitas, multikolinearitas, dan heteroskedastisitas. Hasil pengujian digunakan sebagai dasar dalam membuat simpulan. Simpulan disusun sesuai dengan masalah dan hipotesis penelitian. Model regresi berganda ditunjukan dalam persamaan sebagai berikut:

$\mathrm{Y}=\mathrm{a}+\mathrm{b}_{1} \mathrm{X}_{1}+\mathrm{b}_{2} \mathrm{X}_{2}$

Dimana:

$\mathrm{Y} \quad=$ kepuasan pengguna

a $\quad=$ nilai konstanta

$\mathrm{b}_{1}-\mathrm{b}_{3}=$ koefisien regresi variabel independen

$\mathrm{X}_{1} \quad=$ kualitas layanan

$\mathrm{X}_{2} \quad=$ kualitas sistem

\section{Populasi dan Sampel}

Responden dalam penelitian ini adalah pengguna system Enterprise Resource Planning (ERP) di lingkungan Universitas Padjadjaran yaitu para Pemegang Uang Muka Kerja (PUMK) dilingkungan Universitas Padjadjaran yang menggunakan sistem Enterprise Resource Planning (ERP) yang berjumlah 20 orang.

\section{HASIL DAN PEMBAHASAN}

\section{Uji Validitas, Reliabilitas dan Uji Asumsi Klasik}

Kesahihan (validity) suatu alat ukur adalah kemampuan alat ukur itu untuk mengukur apa yang sebenarnya harus diukur atau dengan perkataan lain alat ukur dapat mengukur indikator-indikator suatu obyek pengukuran. Kesahihan itu perlu sebab pemrosesan data yang tidak sahih atau bias akan menghasilkan simpulan yang tidak benar.

Untuk melihat instrument tersebut valid, maka dilakukan uji validitas dengan cara mengkorelasikan antara skor masing-masing butir pertanyaan terhadap total skor. Bila korelasi antara masing-masing butir terhadap total skor tersebut signifikan maka data tersebut dinyatakan valid.

Berdasarkan hasil tabel 1 diatas, hasil koefisien korelasi setiap pertanyaan dalam variabel kualitas layanan lebih besar dari nilai $r_{\text {tabel }} n=20$ yaitu 0,4683 sehingga semua butir pertanyaan dalam kuesioner kualitas layanan valid. Hasil koefisien korelasi setiap pertanyaan dalam variabel kualitas sistem lebih besar dari niali $r_{\text {tabel }} n=20$ yaitu 0,4683 sehingga semua butir pertanyaan dalam kuesioner kualitas sistem valid. Hasil koefisien korelasi
Tabel 1. Hasil Uji Validitas Kualitas Layanan, Kualitas Sistem dan Kepuasan Pengguna

\begin{tabular}{|c|c|c|c|}
\hline \multicolumn{4}{|c|}{ Kualitas Layanan (X1) } \\
\hline Item & $\mathrm{r}$ tabel & r hitung & Keterangan \\
\hline $\mathrm{P} 1 \mathrm{~A}$ & 0,4683 & 0,548 & Valid \\
\hline $\mathrm{P} 2 \mathrm{~B}$ & 0,4683 & 0,782 & Valid \\
\hline P3 C & 0,4683 & 0,844 & Valid \\
\hline P4 D & 0,4683 & 0,804 & Valid \\
\hline P5 E & 0,4683 & 0,869 & Valid \\
\hline P6 F & 0,4683 & 0,753 & Valid \\
\hline \multicolumn{4}{|c|}{ Kualitas Sistem (X2) } \\
\hline $\mathrm{P} 1 \mathrm{G}$ & 0,4683 & 0,487 & Valid \\
\hline $\mathrm{P} 2 \mathrm{H}$ & 0,4683 & 0,553 & Valid \\
\hline P3 I & 0,4683 & 0,671 & Valid \\
\hline P4 J & 0,4683 & 0,686 & Valid \\
\hline P5 K & 0,4683 & 0,671 & Valid \\
\hline P6 L & 0,4683 & 0,754 & Valid \\
\hline P7M & 0,4683 & 0,716 & Valid \\
\hline P8N & 0,4683 & 0,605 & Valid \\
\hline $\mathrm{P} 9 \mathrm{O}$ & 0,4683 & 0,598 & Valid \\
\hline $\mathrm{P} 10 \mathrm{P}$ & 0,4683 & 0,639 & Valid \\
\hline P11Q & 0,4683 & 0,616 & Valid \\
\hline P12R & 0,4683 & 0,598 & Valid \\
\hline $\mathrm{P} 13 \mathrm{~S}$ & 0,4683 & 0,696 & Valid \\
\hline $\mathrm{P} 14 \mathrm{~T}$ & 0,4683 & 0,510 & Valid \\
\hline $\mathrm{P} 15 \mathrm{U}$ & 0,4683 & 0,489 & Valid \\
\hline $\mathrm{P} 16 \mathrm{~V}$ & 0,4683 & 0,759 & Valid \\
\hline P17W & 0,4683 & 0,489 & Valid \\
\hline \multicolumn{4}{|c|}{ Kepuasan Pengguna (Y) } \\
\hline $\mathrm{P} 1 \mathrm{X}$ & 0,4683 & 0,541 & Valid \\
\hline $\mathrm{P} 2 \mathrm{Y}$ & 0,4683 & 0,679 & Valid \\
\hline P3 Z & 0,4683 & 0,770 & Valid \\
\hline $\mathrm{P} 4 \mathrm{a}$ & 0,4683 & 0,871 & Valid \\
\hline P5 b & 0,4683 & 0,716 & Valid \\
\hline P6 c & 0,4683 & 0,794 & Valid \\
\hline
\end{tabular}

Sumber : Hasil Pengolahan Data Dengan SPSS

setiap pertanyaan dalam variabel kepuasan pengguna lebih besar dari niali $r_{\text {tabel }} n=20$ yaitu 0,4683 sehingga semua butir pertanyaan dalam kuesioner kepuasan pengguna juga valid.

Suatu kuesioner dikatakan reliabel atau handal jika jawaban seseorang terhadap pertanyaan adalah konsisten atau stabil dari waktu ke waktu. Pengukuran reabilitas dalam penelitian ini dilakukan dengan caraone shot. Pengukuran variabel tersebut dilakukan sekali dan kemudian hasilnya dibandingkan dengan pertanyaan lain untuk mengukur korelasi antar jawaban pertanyaan. Ghozali (2013) mengatakan pada umumnya suatu variabel dikatakan reliable jika memberikan nilai cronbach alpha lebih besar dari 0,60.

\section{Tabel 2 Hasil Uji Reliabilitas}

\begin{tabular}{lll}
\hline \multicolumn{1}{c}{ Variabel } & \multicolumn{1}{c}{ Cronbach Alpha } & Keterangan \\
\hline Kualitas Layanan & 0.789 & Reliabel \\
Kualitas Sistem & 0.750 & Reliabel \\
Kepuasan Pengguna & 0.750 & Reliabel \\
\hline
\end{tabular}

Sumber : Hasil Pengolahan Data Dengan SPSS

Berdasarkan tabel 2 diatas, menunjukkan bahwa nilai cronbach alpha masing-masing variabel lebih besar dari 0,6 sehingga alat ukur dalam penelitian ini adalah reliabel. 
Uji normalitas bertujuan untuk menguji apakah model regresi, variabel pengganggu atau residual memiliki distribusi normal.

Tabel 3. Uji Normalitas One-Sampel Kolmogorov-Smirnov Test

\begin{tabular}{|c|c|c|c|c|}
\hline & & $\begin{array}{l}\text { Kualitas } \\
\text { Layanan }\end{array}$ & $\begin{array}{c}\text { Kualitas } \\
\text { Sistem }\end{array}$ & $\begin{array}{l}\text { Kepuasan } \\
\text { Pengguna }\end{array}$ \\
\hline \multicolumn{2}{|l|}{$\mathrm{N}$} & 20 & 20 & 20 \\
\hline \multirow{2}{*}{$\begin{array}{l}\text { Normal } \\
\text { Parameters }{ }^{a, b}\end{array}$} & Mean & 16.70 & 42.40 & 14.85 \\
\hline & $\begin{array}{l}\text { Std. } \\
\text { Deviation }\end{array}$ & 3.114 & 6.320 & 2.961 \\
\hline \multirow{3}{*}{$\begin{array}{l}\text { Most } \\
\text { Extreme } \\
\text { Differences }\end{array}$} & Absolute & .188 & .162 & .130 \\
\hline & Positive & .188 & .162 & .130 \\
\hline & Negative & -.161 & -.075 & -.070 \\
\hline \multicolumn{2}{|l|}{ Test Statistic } & .188 & .162 & .130 \\
\hline \multicolumn{2}{|c|}{ Asymp. Sig. (2-tailed) } & $.062^{\mathrm{c}}$ & $.177^{\mathrm{c}}$ & $.200^{\mathrm{c}, \mathrm{d}}$ \\
\hline \multicolumn{5}{|c|}{ a. Test distribution is Normal. } \\
\hline \multicolumn{5}{|c|}{ b. Calculated from data. } \\
\hline \multicolumn{5}{|c|}{ c. Lilliefors Significance Correction. } \\
\hline \multicolumn{5}{|c|}{ d. This is a lower bound of the true significance. } \\
\hline
\end{tabular}

Sumber: Hasil Pengolahan Data Dengan SPSS

Berdasarkan tabel 3 diatas, dapat dilihat bahwa nilai signifikan asymp.sig (2-Tailed) sebesar 0.200 lebih besar dari 0.05 . jadi dapat disimpulkan bahwa data yang diuji dalam penelitian ini berdistribusi normal.

Uji heteroskedastisitas bertujuan untuk menguji seluruh apakah dalam model regresi terjadi ketidaksamaan varians dari residual satu pengamatan ke pengamatan yang lain. Jika variance dari residual satu pengamatan ke pengamatan lain tetap, maka disebut homokedastisitas dan jika berbeda disebut heteroskedastisitas. Untuk mengetahui ada tidaknya pola tertentu pada grafik Scatterplot dengan ketentuan:

1. jika terdapat pola tertentu, seperti titik-titik yang ada membentuk pola tertentu yang teratur maka menunjukkan telah terjadi heteroskedastisitas.

2. Jika tidak ada pola yang jelas, serta titik-titik menyebar diatas dan dibawah angka 0 pada sumbu Y, maka tidak terjadi heteroskedastisitas.

Berdasarkan dari pola scatterplot diatas menunjukkan hasil out put SPSS gambar scatterplot didapatkan

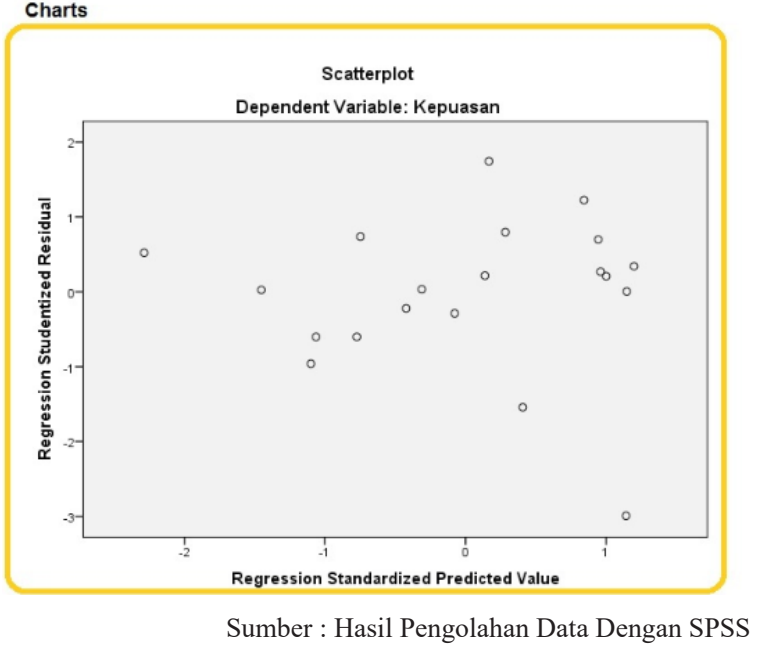

\section{Gambar 2 Hasil Uji Heteroskedastisitas}

titik-titik menyebar dibawah dan diatas sumbu Y dan tidak mempunyai pola yang teratur, sehingga dapat disimpulkan bahwa gambar diatas menunjukkan tidak terjadi heteroskedastisitas.

Uji multikolinearitas bertujuan untuk mengetahui apakah dalam suatu model regresi terdapat korelasi antar variabel independen penelitian. Model regresi yang baik seharusnya tidak terjadi korelasi antar variabel independen. Ada tidaknya korelasi dapat dideteksi dengan melihat nilai tolerance dan lawannya dengan uji tes Variance Inflation Factor (VIF). Jika nilai tolerance $>0,10$ dan VIF $<10$ maka tidak terdapat multikolinearitas antar variabel independen.

Analisis regresi dilakukan bila hubungan dua variabel berupa hubungan kausal atau fungsional. Karena dalam penelitian ini terdapat 2 variabel independen (kualitas layanan, dan kualitas sistem) maka digunakan analisis regresi berganda.

Berdasarkan tabel 4 Coefficients diatas, dengan menggunakan VIF diperoleh nilai sebagai berikut: kualitas layanan nilai tolerance sebesar 0,548 dan VIF sebesar 1,825. Kualitas sistem nilai tolerance sebesar 0,548 dan VIF 1,825. Maka dapat disimpulkan bahwa multikolinieritas tidak mempunyai masalah yang besar, sehingga data terbebas dari gejala multikolinieritas.

\section{Tabel 4. Uji Multikolinearitas dan Hasil Uji Analisis Regresi Berganda}

\begin{tabular}{|c|c|c|c|c|c|c|c|c|}
\hline \multicolumn{9}{|c|}{ Uji Multikolinearitas } \\
\hline \multicolumn{9}{|c|}{ Coefficients $^{\mathbf{a}}$} \\
\hline & & \multicolumn{2}{|c|}{$\begin{array}{c}\text { Unstandardized } \\
\text { Coefficients }\end{array}$} & \multirow{2}{*}{$\begin{array}{l}\text { Standardized } \\
\text { Coefficients } \\
\text { Beta }\end{array}$} & \multirow[t]{2}{*}{$\mathrm{t}$} & \multirow[t]{2}{*}{ Sig. } & \multicolumn{2}{|c|}{ Collinearity Statistics } \\
\hline & & B & Std. Error & & & & Tolerance & VIF \\
\hline \multirow[t]{3}{*}{1} & (Constant) & -.714 & 2.345 & & -.304 & .765 & & \\
\hline & Kualitas Layanan & .702 & .148 & .739 & 4.746 & .000 & .548 & 1.825 \\
\hline & Kualitas Sistem & .090 & .073 & .193 & 1.241 & .231 & .548 & 1.825 \\
\hline \multicolumn{9}{|c|}{ Uji Analisis Regresi Berganda } \\
\hline \multirow[t]{3}{*}{1} & (Constant) & -1.791 & 1.407 & & -1.273 & .220 & & \\
\hline & Kualitas Layanan & .113 & .089 & .368 & 1.274 & .220 & .548 & 1.825 \\
\hline & Kualitas Sistem & .021 & .044 & .141 & .487 & 632 & .548 & 1.825 \\
\hline
\end{tabular}


Hasil pengujian terhadap koefisien menghasilkan model sebagai berikut:

$\mathrm{Y}=-\mathbf{1 . 7 9 1}+\mathbf{0 . 1 1 3} \mathrm{KL}+\mathbf{0 . 2 1} \mathrm{KS}$

Berdasarkan persamaan regresi diatas dapat diinterpretasikan sebagai berikut :

1. Koefisien konstanta sebesar (1.791) dengan nilai negatif, ini dapat diartikan bahwa kepuasan pengguna akan bernilai (1.791) apabila masing-masing variabel kualitas layanan, dan kualitas sistem bernilai 0 .

2. Variabel kualitas layanan memiliki koefisien 0.113 . Nilai koefisien regresi positif menunjukkan bahwa kualitas layanan berpengaruh positif terhadap kepuasan pengguna. Hal ini menggambarkan bahwa jika setiap kenaikan satu persen variabel kualitas layanan, dengan asumsi variabel lain tetap maka akan meningkatkan kepuasan pengguna sebesar 0,113 .

3. Variabel kualitas sistem memiliki koefisien regresi sebesar 0.021 nilai koefisien regresi poisitif menunjukkan bahwa kualitas sistem berpengaruh positif terhadap kepuasan pengguna. Hal ini menggambarkan bahwa jika setiap kenaikan satu persen variabel kualitas sistem, dengan asumsi variabel lain tetap maka akan meningkatkan kepuasan pengguna sebesar 0.021.

Koefisien Determinasi (KD) merupakan kuadrat dari koefisien korelasi (R) atau disebut juga sebagai R-Square. Koefisien determinasi digunakan untuk menghitung besarnya pengaruh variabel bebas (kualitas layanan $\left(\mathrm{X}_{1}\right)$, kualitas sistem $\left(\mathrm{X}_{2}\right)$ terhadap variabel tergantung (kepuasan pengguna (Y)), Dengan menggunakan SPSS, diperoleh hasil koefisien determinasi pada tabel 5.

Tabel 5. Hasil Uji Koefisien Determinasi $\left(\mathbf{R}^{2}\right)$

\begin{tabular}{|c|c|c|c|c|}
\hline \multicolumn{5}{|c|}{ Model Summary } \\
\hline Model & $\mathrm{R}$ & $\begin{array}{c}\mathrm{R} \\
\text { Square }\end{array}$ & $\begin{array}{l}\text { Adjusted R } \\
\text { Square }\end{array}$ & $\begin{array}{l}\text { Std. Error of the } \\
\text { Estimate }\end{array}$ \\
\hline 1 & $.880^{\mathrm{a}}$ & .775 & .748 & 1.486 \\
\hline
\end{tabular}

Sumber : Hasil Pengolahan Data Dengan SPSS
Hasil pengujian terhadap koefisien menghasilkan model sebagai berikut: $\mathrm{KD}=0,775 \times 100 \%$

Dari hasil perhitungan diatas, diperoleh angka ( $\mathrm{R}$ square) sebesar 0.775 atau (77,5\%). Hal ini menunjukkan bahwa persentase pengaruh variabel kualitas layanan $\left(\mathrm{X}_{1}\right)$ kualitas sistem $\left(\mathrm{X}_{2}\right)$ terhadap variabel dependen kepuasan pengguna (Y) sebesar 75,5\% hal tersebut menunjukkan bahwa terdapat korelasi yang sangat tinggi sebesar 0,880 antara kualitas layanan, dan kualitas sistem terhadap kepuasan pengguna. Sedangkan sisanya yautu sebesar 22,5\% dipengaruhi oleh faktor lain diluar model penelitian ini.

Uji statistik t disebut juga uji signifikan individual. Uji ini menunjukkan seberapa jauh pengaruh variabel independen secara parsial terhadap variabel dependen. Pada akhirnya akan diambil suatu simpulan Ho ditolak atau $\mathrm{Ha}$ diterima dari hipotesis yang telah dirumuskan.

Uji F (uji simultan) dilakukan untuk mengetahui koefisien secara keseluruhan. Uji ini digunakan untuk menguji pengaruh secara bersama-sama antara kualitas layanan, kualitas sistem terhadap kepuasan pengguna. Adapun hasil pengujiannya dijelaskan pada Tabel 6 .

Hasil yang diperoleh dari uji t berdasarkan tabel 6 diatas adalah sebagai berikut:

\section{Variabel kualitas layanan $\left(X_{1}\right)$}

Berdasarkan tabel Coefficient diatas nilai signi-fikansi untuk variabel kualitas layanan sebesar 0,000 , dibandingkan dengan taraf signifikansi $(\alpha=0,05)$ maka $0,000<0,05$. Dapat disimpulkan bahwa Ho ditolak dan $\mathrm{Ha}$ diterima berarti bahwa kualitas layanan berpengaruh positif dan signifikan terhadap kepuasan pengguna. atau, dalam tabel Coefficient diperoleh nilai $\mathrm{t}_{\text {tabel }}$ sebesar 2,110 (diperoleh dengan cara mencari nilai $\mathrm{df}=\mathrm{n}-\mathrm{k}=20-3=17$, dan nilai $\alpha=5 \%$ dibagi menjadi dua yaitu $5 \% / 2=0,025)$ dan nilai $\mathrm{t}_{\text {hitung }}$ sebesar 4,746. Karena nilai $\mathrm{t}_{\text {hitung }}>\mathrm{t}_{\text {tabel }}$ yaitu $(4,746$ $>2,110)$, maka dapat disimpulkan bahwa Ho ditolak dan Ha diterima yang berarti bahwa kualitas layanan memiliki pengaruh positif terhadap kepuasan pengguna.

Tabel 6. Hasil Uji T dan Uji F

\begin{tabular}{|c|c|c|c|c|c|c|c|}
\hline \multicolumn{8}{|c|}{ Uji T Parsial } \\
\hline \multicolumn{8}{|c|}{ Coefficients $^{\mathrm{a}}$} \\
\hline \multirow{2}{*}{\multicolumn{3}{|c|}{$\begin{array}{c}\text { Model } \\
\text { B } \\
\text { Std. Error }\end{array}$}} & \multicolumn{2}{|c|}{ Unstandardized Coefficients } & Standardized Coefficients & \multirow[b]{2}{*}{$\mathrm{t}$} & \multirow[b]{2}{*}{ Sig. } \\
\hline & & & Beta & & & & \\
\hline \multirow{3}{*}{\multicolumn{2}{|c|}{$\begin{array}{l}1 \\
\text { Kualitas Layanan } \\
\text { Kualitas Sistem }\end{array}$}} & (Constant) & -.714 & 2.345 & & -.304 & .765 \\
\hline & & .702 & .148 & .739 & 4.746 & .000 & \\
\hline & & .090 & .073 & .193 & 1.241 & .231 & \\
\hline \multicolumn{8}{|c|}{ Uji F Simultan } \\
\hline \multicolumn{8}{|c|}{ ANOVA $^{a}$} \\
\hline Model & \multicolumn{2}{|c|}{ Sum of Squares } & $\mathrm{df}$ & Mean Square & $\mathrm{F}$ & Sig. & Model \\
\hline \multirow[t]{3}{*}{1} & \multicolumn{2}{|l|}{ Regression } & 128.997 & 2 & 64.498 & 29.198 & $.000^{b}$ \\
\hline & \multicolumn{2}{|l|}{ Residual } & 37.553 & 17 & 2.209 & & \\
\hline & \multicolumn{2}{|l|}{ Total } & 166.550 & 19 & & & \\
\hline \multicolumn{8}{|c|}{ a. Dependent Variable: Kepuasan Pengguna } \\
\hline \multicolumn{8}{|c|}{ b. Predictors: (Constant), Kualitas Sistem, Kualitas Layanan } \\
\hline
\end{tabular}




\section{Variabel Likuiditas $\left(\mathbf{X}_{2}\right)$}

Berdasarkan tabel Coefficient diatas nilai signifikansi untuk variabel kualitas sistem sebesar 0,231, dibandingkan dengan taraf signifikansi $(\alpha=0,05)$ maka $0,231>0,05$. Dapat disimpulkan bahwa Ho diterima dan Ha ditolak berarti bahwa kualitas system tidak berpengaruh signifikan terhadap kepuasan pengguna. atau, dalam tabel Coefficient diperoleh nilai $t_{\text {tabel }}$ sebesar 2,110 (diperoleh dengan cara mencari nilai $\mathrm{df}=\mathrm{n}-\mathrm{k}=$ $20-3=17$, dan nilai $\alpha=5 \%$ dibagi menjadi dua yaitu $5 \% / 2$ $=0,025)$ dan nilai $t_{\text {hitung }}$ sebesar 1,241 . Karena nilai $\mathrm{t}_{\text {hitung }}<$ $\mathrm{t}_{\text {tabel }}$ yaitu 1,241<2,110, maka dapat disimpulkan bahwa Ho diterima dan Ha ditolak yang berarti bahwa kualitas system tidak berpengaruh signifikan terhadap kepuasan pengguna.

Sedangkan hasil yang diperoleh dari uji $\mathrm{F}$ berdasarkan tabel 6 diatas diperoleh nilai $\mathrm{F}_{\text {hitung }}$ sebesar 29,198. Dan $F_{\text {tabel }}$ adalah 3,59. Jadi, karena pada penelitian ini. Apabila $\mathrm{F}_{\text {hitung }}$ lebih besar dari $\mathrm{F}_{\text {tabel }}$ yaitu 29,198 $>$ 3,59, maka hipotesis penelitian adalah signifikan. Secara besama-sama kualitas layanan, kualitas sistem berpengaruh signifikan terhadap kepuasan pengguna.

\section{Pengaruh Kualitas Layanan terhadap Kepuasan Pengguna}

Dari hasil uji regresi secara parsial, diperoleh hasil yang mengungkapkan bahwa variabel kualitas layanan memiliki pengaruh positif terhadap kepuasan pengguna. Karena nilai $t_{\text {hitung }}>t_{\text {tabel }}$ yaitu $(4,746>2,110)$, maka dapat disimpulkan bahwa kualitas layanan yang diberikan oleh vendor sekaligus sebagai konsultan aplikasi sistem Enterprise Resource Planning (ERP) mampu memberikan kepuasan kepada pengguna sistem dilingkungan Universitas Padjadjaran. Hal tersebut menunjukkan semakin tinggi nilai kualitas layanan yang diberikan oleh pihak vendor dan konsultan semakin tinggi pula kepuasan yang dirasakan oleh pengguna aplikasi sistem Enterprise Resource Planning (ERP) dilingkungan Universitas Padjadjaran. Indikator yang paling mempengaruhi kepuasan pengguna sistem Enterprise Resource Planning (ERP) dilingkungan Universitas Padjadjaran adalah indikator kecepatan tanggap yaitu staff penyedia sistem Enterprise Resource Planning (ERP) akan memberikan layanan dengan cepat/segera. Hal tersebut dapat diartikan bahwa staff dari pihak vendor merupakan orang-orang yang cepat tanggap dalam memberikan layanan apabila para pengguna merasa kesusahan dalam mengolah datamaupun kurang mengerti dengan fitur-fitur yang terdapat di aplikasisistem Enterprise Resource Planning (ERP). Dengan kecepatan tanggap dari para staff vendor membuat para pengguna merasa aman dan nyaman saat menggunakan aplikasi sistem Enterprise Resource Planning (ERP).

Hasil tersebut sesuai dengan penelitian yang telah dilakukan Asnawi (2014) dan Prasojo (2015) yang menunjukkan bahwa kualitas layanan berpengaruh positif dan signifikan terhadap kepuasan pengguna.
Selain itu, hasil dari penelitian ini juga mendukung model keberhasilan sistem informasi DeLone dan McLean (2003) yang menyatakan kualitas layanan berpengaruh terhadap kepuasan pengguna. Responden dalam penelitian ini secara empiris menunjukkan bahwa kualitas layanan memiliki pengaruh positif terhadap kepuasan pengguna. Hal ini mengindikasikan vendor yang memiliki peran sebagai konsultan telah memberikan layanan yang sesuai dengan ekspektasi pengguna sistem Enterprise Resource Planning (ERP) dilingkungan Universitas Padjadjaran sehingga meningkatkan kepuasan pengguna aplikasi sistem Enterprise Resource Planning (ERP).

\section{Pengaruh Kualitas Sistem terhadap Kepuasan Pengguna}

Dari hasil uji regresi secara parsial, diperoleh hasil yang mengungkapkan bahwa variabel kualitas sistem tidak berpengaruh signifikan terhadap kepuasan pengguna karena nilai $\mathrm{t}_{\text {hitung }}<\mathrm{t}_{\text {tabel }}$ yaitu 1,241 $<2,110$, hal ini berarti bahwa kualitas sistem yang dihasilkan oleh sistem Enterprise Resource Planning (ERP) tidak sesuai dengan kebutuhan dan keinginan pengguna. Ketidakpuasan pengguna sistem Enterprise Resource Planning (ERP) terhadap kualitas sistem disebabkan oleh keterbatasan server sistem maupun jaringan internet, keterbatasan pengetahuan para pengguna tentang sistem Enterprise Resource Planning (ERP), masih rendahnya keterlibatan pengguna melalui sikap positif pengguna terhadap sistem Enterprise Resource Planning (ERP) yaitu dalam bentuk dukungan dan kompetensi dari pengguna itu sendiri serta belum terbinanya hubungan yang baik antara pengguna dengan teknisi. Selain itu kurangnya keterlibatan pengguna dalam desain dan operasi sistem Enterprise Resource Planning (ERP) sehingga pengguna kurang memiliki kesempatan untuk mendesain sistem tersebut sesuai dengan kebutuhannya dan kesempatan untuk mengontrol hasilnya. Untuk itu Universitas Padjadjaran perlu meningkatkan server sistem maupun jaringan internet agar dapat meminimalisir adanya gangguan sistem seperti putusnya jaringan yang menyebabkan server mati yang akhirnya berdampak pada kecepatan akses dan keandalan sistem yang dapat mengganggu kenyamanan pengguna sehingga berdampak pada kepuasan pengguna. Selain itu Universitas Padjadjaran harus menyelenggarakan pelatihan dan sosialisasi menyeluruh kepada pengguna sistem Enterprise Resource Planning (ERP), memberikan motivasi kepada para pengguna untuk bersikap positif terhadap sistem Enterprise Resource Planning (ERP). Sedangkan untuk indikator kemudahan, fleksibilitas dan keamanan harus tetap dipertahankan pada sistem Enterprise Resource Planning (ERP) yang sekarang berjalan.

Hasil tersebut sesuai dengan penelitian yang dilakukan oleh Agustina (2018) yang menunjukkan kuali-tas sistem tidak berpengaruh terhadap kepuasan pengguna. Selain itu, hasil dari penelitian ini juga tidak mendukung 
di Lingkungan Universitas Padjadjaran

model keberhasilan sistem informasi DeLone dan McLean (1992) yang menyatakan bahwa kualitas sistem (sistem quality) dapat mempengaruhi kepuasan pengguna (user satisfaction). Begitupun menurut DeLone dan McLean (2003) yang menyatakan bahwa kualitas sistem baik secara individual dan bersama-samamempengaruhi kepuasan penggunanya. Responden dalam penelitian ini secara empiris menunjukkan bahwa kualitas sistemtidak berpengaruh signifikan terhadap kepuasan pengguna

\section{Pengaruh Kualitas Layanan dan Kualitas Sistem terhadap Kepuasan Pengguna}

Hasil penelitian terhadap kepuasan pengguna sistem Enterprise Resource Planning (ERP) ditemukan adanya pengaruh secara simultan atau secara bersama-sama dari layanan dan kualitas sistem terhadap kepuasan pengguna sistem Enterprise Resource Planning (ERP).Hal ini dapat dilihat dari nilai $\mathrm{F}_{\text {hitung }}$ sebesar 29,198. Dan $\mathrm{F}_{\text {tabel }}$ adalah 3,59. Apabila $\mathrm{F}_{\text {hitung }}$ lebih besar dari $\mathrm{F}_{\text {tabel }}$ yaitu 29,198 > 3,59. Hal tersebut semakin baik kualitas layanan dan kualitas sistem yang dihasilkan olehsistem Enterprise Resource Planning (ERP) maka kepuasan pengguna akan meningkat, sehingga akan mempermudah pekerjaan para penggunanya.

Hasil tersebut sesuai dengan penelitian yang telah dilakukan Asnawi (2014), Prasojo (2015), begitupun dengan Agustina (2018)yang menunjukkan bahwa secara simultan kualitas sistem, kualitas informasi, dan kualitas layanan berpengaruh signifikan terhadap kepuasan pengguna. Responden dalam penelitian ini secara empiris menunjukkan bahwa kualitas layanan dan kualitas sistem secara bersama sama berpengaruh signifikan terhadap kepuasan pengguna

\section{SIMPULAN}

Berdasarkan hasil analisa dan pengolahan data pada penelitian ini, maka dapat disimpulkan beberapa hal mengenai peran kualitas layanan dan kualitas sistem dalam meningkatkan kepuasan pengguna pada pengguna sistem Enterprise Resource Planning (ERP) di Lingkungan Universitas Padjadjaran sebagai berikut:

Secara parsial, kualitas layanan memiliki pengaruh positif terhadap kepuasan pengguna. Hal ini bisa dilihat dari semakin baik kualitas layanan yang diberikan oleh penyedia sistem Enterprise Resource Planning (ERP) di Universitas Padjadjaran seperti fasilitas fisik yang memadai, layanan yang cepat dan akurat, melayani dengan tanggap, memberikan keyakinan terhadap pengguna dan memberikan komunikasi yang baik serta memahami keinginan pengguna. Hal tersebutakan meningkatkan kepuasan pengguna sistem Enterprise Resource Planning (ERP) di lingkungan Universitas Padjadjaran.

Secara parsial, kualitas sistem tidak berpengaruh signifikan terhadap kepuasan pengguna.Hal ini dapat disimpulkan bahwa kualitas sistem Enterprise Resource Planning
(ERP) di Universitas Padjadjaran masih rendah atau belum cukup baik. Hal tersebut mungkin disebabkan oleh masih belum memadainya diselenggarakan pelatihan dan sosialisasi menyeluruh kepada pengguna sistem Enterprise Resource Planning (ERP), masih rendahnya keterlibatan pengguna melalui sikap positif pengguna terhadap sistem Enterprise Resource Planning (ERP) yaitu dalam bentuk dukungan dan kompetensi dari pengguna itu sendiri serta belum terbinanya hubungan yang baik antara pengguna dengan teknisi. Selain itu kurangnya keterlibatan pengguna dalam desain dan operasi sistem Enterprise Resource Planning (ERP) sehingga pengguna kurang memiliki kesempatan untuk mendesain sistem tersebut sesuai dengan kebutuhannya dan kesempatan untuk mengontrol hasilnya. Dengan demikian kepuasan pengguna tidak terpengaruhi secara signifikan. Secara simultan kualitas layanan dan kualitas sistem berpengaruh signifikan terhadap kepuasan pengguna.

\section{DAFTAR PUSTAKA}

Agustina (2018), Faktor-faktor Kepuasan Pengguna SAP dalam Menyusun Laporan Keuangan(Studi Kasus pada PT.INTI Bandung).e-Proceeding of Management, 5, 2, 2092-2097.

Amalia (2016), Pengaruh Kualitas Sistem Informasi, Kualitas Informasi dan Perceived Usefulness Terhadap Kepuasan Pengguna Sistem Informasi Akuntansi (Studi Pada Pengguna Sistem Informasi Akuntansi di Rumah Sakit Mata Cicendo Bandung).e-Proceeding of Management, 3, 2, 1516-1522.

Asnawi(2014), Pengaruh Kualitas Sistem, Kualitas Informasi, kualitas Layanan, dan Partisipasi Pengguna Terhadap Sistem: Studi Kasus Pada Bagian Operasional VSAT IP PT. Semesta Citra Media. JURNAL LENTERA ICT, 2, 1, 37-50.

DeLone \& Mclean (1992), Information system success: the quest for the dependent variable. Information System Research, March, 3, 1, 60-95.

DeLone \& McLean (2003), The delone and mclean model of information system success: a ten-years update, Journal of Management Information System, Spring. 19, 4, 9-30.

Ghojali (2013). Aplikasi Analisis Multivariate dengan Program SPSS. Edisi Ketujuh. Semarang: Badan Penerbit Universitas Diponegoro.

Hendriyanah, A.Unpad Kembangkan dan Implementasikan Sistem ERP Berbasis Oracle.http://www.unpad. ac.id/2016/07/. (diakses 03 November 2018)

Istianingsih, dan Wijanto. (2008), Pengaruh Kualitas Sistem Informasi, Perceived Usefulness, dan Kualitas Informasi Terhadap Kepuasan Pengguna 
Akhir Software Akuntansi, Simposium Nasional Akuntansi XI, 1-51.

Jogiyanto (2007). Model Kesuksesan Sistem Teknologi Informasi. Yogyakarta: Andi Offset

Komara (2006).Analisis Faktor-Faktor yang mempengaruhi Kinerja Sistem Informasi Akuntansi.Jurnal MAKSI, 6, 2, 143-160.

Kotler (2009). Manajemen Pemasaran, Edisi 13. Jakarta: Erlangga

Prasojo (2015), Pengaruh Kualitas Informasi, Kualitas Sistem dan Kualitas Layanan Aplikasi Rail Ticket System (RTS) Terhadap Kepuasan Pengguna Sistem (Studi Kasus pada PT. Kereta Api Indonesia (Persero) DAOP 2 Bandung). e-Proceeding of Management, 2, 1, 555-562.

Rambat (2014).Manajemen Pemasaran Jasa. Edisi 3. Jakarta: Salemba Empat.
Rukmiyati dan Budiartha (2016). Pengaruh Kualitas Sistem Informasi, Kualitas Informasi dan Perceived Usefulness Pada Kepuasan Pengguna Akhir Software Akuntansi (Studi Empiris Pada Hotel Berbintang di Provinsi Bali). E-Jurnal Ekonomi dan Bisnis Universitas Udayana, 5, 1, 115-142

Susanto (2013), Sistem Informasi Akuntansi, Struktur Pengendalian Resiko Pengembangan, Edisi Perdana. Bandung: Lingga Jaya.

Tananjaya (2012). Kualitas Sistem Informasi, Kualitas Informasi, Dan Perceived Usefulness Terhadap Keberhasilan Implementasi Software Akuntansi. Berkala Ilmiah Mahasiswa Akuntansi Universitas Katolik Widya Mandala Surabaya, 1, 3, 65-69.

Tjiptono (2014).Pemasaran Jasa - Prinsip, Penerapan, dan Penelitian. Yogyakarta: Andi Offset

Tjiptono, dan Chandra (2012), Pemasaran Strategik. Yogyakarta: Andi Offset 